\title{
Influence of Loan Interest Rate, Non-Performing Loan, Third Party Fund and Inflation Rate towards Micro, Small and Medium Enterprises (MSME) Credit Lending Distribution at Commercial Banks in Indonesia
}

\author{
Akhmad Darmawan \\ Faculty of Economics and Business, Universitas Muhammadiyah Purwokerto \\ akhmaddarmawan@ump.ac.id/drmpasca@yahoo.com
}

\begin{abstract}
This study employs a quantitative study approach to determine the effect of Loan Interest Rate, Non-Performing Loan (NPL), Third Parties Fund (DPK) and Inflation Rate on Micro, Small and Medium Enterprises (MSME) Credit Lending Distribution of commercial banks listed in Indonesian Stock Exchange during 2013-2015 period. The analysis technique used in this study was multiple linear regression and used secondary data published by Indonesia Stock Exchange. There were 39 samples in this study taken by using purposive sampling technique. The result of the study showed that Loan Interest Rate, Non-Performing Loan (NPL), Third Parties Fund (DPK) and Inflation Rate have simultaneous effect on MSME credit lending distribution of commercial banks in Indonesia. The result defines that only Third Parties Fund has positive significant effect on MSME credit loan. Third Parties Fund has the biggest effect in this study while loan interest rate, NPL, and inflation rate has no effect on MSME credit lending.
\end{abstract}

Keywords: Non Performing Loan, Third Parties Fund, Inflation Rate, Micro, MSME Credit Lending Distribution

\section{INTRODUCTION}

Economic growth in Indonesia is inseparable from the role of MSMEs. This sector is significantly instrumental in employment absorption and reached $93.36 \%$ greater than large businesses that only reached $3.64 \%$. There is also a big contribution of MSMEs sector in determining the Gross Domestic Product and the country's foreign exchange earnings for about $60.34 \%$.

There are some internal factors of banking that affect the credit lending distribution, which are Loan Interest Rates, Non-Performing Loan and Third Party Fund. In addition, there is also an external factor that affect the credit lending distribution, which is inflation rate. [3] bank loan interest rates can be interpreted as compensation provided by banks based on conventional principles to customers who buy or sell their products. Increased in interest rates worsen the quality of loans, the higher the cost of debt makes the debtor increasingly difficult to pay the loan. In addition, high interest rates are a potentially disadvantageous alternative to debtors [1]

Non-Performing Loan is measured by the high ratio of Non-Performing Loan. It means that higher NPL will result in higher risk of non-performing loans borne by the bank. Due to the high non-performing loans, banks have to provide greater reserves that eventually makes bank capital decreased. In other side, the amount of bank capital greatly influences the extent of credit expansion.

Third Party Funds have an important role in credit lending distribution. Third Party Funds are the funds raised from the society and are the largest source of funds that most depended by banks [2]. Third Party Funds is a highly influential factor on credit lending distribution because Third Party Funds becomes the measures of credit size that are able to be distributed by banks. Due to the high and low Third Party Funds of a bank is a reflection of the ability of banks in distributing its credit lending.

Citra (2013) The external factors affecting credit lending distribution is inflation. [4] Inflation is the rise of prices in general prevailing in an economy from one period to another. [1] inflation is the condition of lower money exchange rate or increasing of the price of goods and services. Therefore, the inflation rate affects the interest rate which will affect the volume of credit given by banks. Above, this study aims to determine the effects of Loan Interest Rate, Non-Performing Loan, Third Parties Fund and Inflation Rate towards MSME Credit Lending Distribution of commercial banks in Indonesia.

\section{LITERATURE REVIEW}

\section{Bank Theory}

In general, the main function of banks is to raise funds from the society and distribute it back to the society for various purposes or as a financial intermediary. More specifically, bank functions can be 
act as agents of trust, agent of development, and agent of services [5].

\section{Loan Interest Rate}

Loan interest rate is the interest given to the lender or the price that should be paid by the borrowers to the bank [2]

2 Non-Performing Loan

Non-Performing Loan is the ratios used to measure the bank's ability to cover the default risk in credit repayments by debtors. NPL reflect credit risk, the smaller the NPL the less the credit risk borne by the bank.

3 Third Parties Fund

Third Party Funds (DPK) are funds collected from the society in the form of giro, savings, and deposits. Third party funds are inputs in credit lending distribution. The more third party funds collected, the easier for the bank in doing credit lending distribution to the party in need [2]

4 Inflation

Inflation is a tendency of increasing price of goods in general continuously due to the excessive amount of money in market circulation compared to the goods and services available [6].

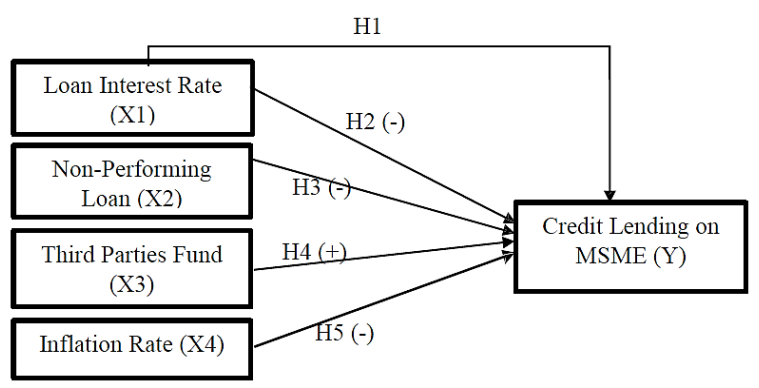

Figure 1. Theoretical Framework

\section{Research Hypotheses}

In this study, the hypothesis proposed and will be tested are as follows:

H1 : Loan Interest Rate, Non-Performing Loan, Third Parties Fund, and Inflation Rate have simultaneous effect on MSME Credit Lending Distribution

H2 : Loan Interest Rate has a negative effect on MSME Credit Lending Distribution

H3 : Non-Performing Loan has a negative effect on MSME Credit Lending Distribution

H4 : Third Parties Fund has a positive effect on MSME Credit Lending Distribution

H5 : Inflation Rate has a negative effect on MSME Credit Lending Distribution

\section{METHOD}

This research employs quantitative research design. The population used in this study is banking companies listed in Indonesia Stock Exchange and there are 13 sample companies that were taken by using purposive sampling method.

\section{Operational Definition and Variable Measurement}

1 Dependent Variable (Y)

The dependent variable in this research is the MSME credit lending distribution of commercial banks in Indonesia

2 Independent Variables

a. Loan Interest Rate (X1)

Loan interest rate used in this research is average of loan interest rate charged by each bank to the borrowers or lenders.

b. Non-Performing Loan (X2)

Non-Performing Loan refers to the failure of debtors in returning the loans to the bank.

c. Third Parties Fund (X3)

Third Party Funds (DPK) are funds collected from the society in the form of giro, savings, deposits [2]. The formula of Third Party Funds are as follows: Third Parties Fund $=($ Giro + Savings + Deposits $)$

d. Inflation Rate (X4)

The inflation rate can be calculated by the following formula:

Inflation Rate $=$ Consumer Price Index Period $n$ -

Consumer Price Index of the previous year

\section{Classical Assumption Test}

The data has passed from all of classical assumption test which are normality test, multicollinearity test, heteroscedasticity test, and autocorrelation test.

Multiple Linear Regression Analysis

Tabel 1. Results of Multiple Linear Regression Analysis

\begin{tabular}{|c|c|c|c|c|c|}
\hline \multirow[t]{2}{*}{ Model } & \multicolumn{2}{|c|}{$\begin{array}{c}\text { Unstandardized } \\
\text { Coefficients }\end{array}$} & \multirow{2}{*}{$\begin{array}{c}\begin{array}{c}\text { Standardized } \\
\text { Coefficients }\end{array} \\
\text { Beta }\end{array}$} & \multirow[t]{2}{*}{$\mathrm{T}$} & \multirow[t]{2}{*}{ Sig. } \\
\hline & $\mathrm{B}$ & Std. Error & & & \\
\hline (Constant) & -.106 & 2.410 & & -.044 & .965 \\
\hline Interest Rate & .011 & .039 & .019 & .282 & .780 \\
\hline NPL & -.143 & .184 & -.051 & -.776 & .444 \\
\hline DPK & .950 & .067 & .936 & 14.121 & .000 \\
\hline Inflation Rate & .003 & .056 & .004 & .059 & .954 \\
\hline
\end{tabular}

a. Dependent Variable: Credit Lending MSME

Source: Output SPSS 22, 2017

Based on the table 1 can be seen that the following multiple linear regression equation is formed:

$\mathrm{Y}=0,106+0,011 \mathrm{X} 1-0,143 \mathrm{X} 2+0,950 \mathrm{X} 3+$ $0,003 \times 4$

And the anti-Ln equation is as follows:

$\mathrm{Y}=0,899+1,011 \mathrm{X} 1+0,867 \mathrm{X} 2+2,586 \mathrm{X} 3+1,003 \mathrm{X} 4$

Where:

$\mathrm{Y}=$ Micro, Small and Medium Enterprises (MSME)

Credit Lending Distribution

$\mathrm{X} 1=$ Loan Interest Rate

X2 = Non-Performing Loan (NPL)

X3 = Third Parties Fund (DPK)

X4 = Inflation Rate 


\section{F test (Simultaneous) First Hypothesis}

Table 2. F Test Results

\begin{tabular}{|c|c|c|c|c|c|}
\hline Model & Sum of & $\mathrm{D}$ & Mean Square & $\mathrm{F}$ & Sig. \\
\hline 1 & 109.56 & 4 & 27.39 & 52.32 & .000 \\
\hline Residual & 15.70 & 30 & .523 & & \\
\hline Total & 125.26 & 34 & & & \\
\hline \multicolumn{6}{|c|}{ a. Dependent Variable: Credit Lending } \\
\hline
\end{tabular}

Table 2 showed that Loan Interest Rate, NonPerforming Loan (NPL), Third Parties Fund (DPK) and Inflation Rate simultaneously have significant effect on MSME credit lending distribution of commercial banks in Indonesia. Therefore, the first hypothesis is accepted.

t-Test (Partial)

Second Hypothesis

Table 1 showed that Loan Interest Rate has positive insignificant effect on MSME credit lending distribution. Therefore, the second hypothesis is rejected.

Third Hypothesis

Table 1 showed that Non-Performing Loan variable has negative insignificant effect on MSME credit lending distribution. Therefore, the third hypothesis is rejected.

Fourth Hypothesis

Table 1 showed that the Third Party Fund (DPK) variable has positive significant effect on MSME credit lending distribution. Therefore, the fourth hypothesis is accepted. Fifth Hypothesis

Table 1 showed that the inflation variable has positive insignificant effect on MSME credit lending distribution. Therefore, the fifth hypothesis is rejected.

\section{Coefficient of Determination}

The coefficient of determination (Adjusted R2) essentially measures how far the model's ability to explain the dependent variable.

Table 3. Adjusted R Square Test Results

\begin{tabular}{|c|c|c|c|c|}
\hline \multicolumn{5}{|c|}{ Model Summary } \\
\hline Model & $\mathrm{R}$ & R Square & $\begin{array}{c}\text { Adjusted R } \\
\text { Square }\end{array}$ & $\begin{array}{l}\text { Std. Error } \\
\text { of the }\end{array}$ \\
\hline 1 & $.935^{\mathrm{a}}$ & .875 & .858 & .72352 \\
\hline
\end{tabular}

The value of Adjusted R Square is 0.858 or $(85.8 \%)$ means that $85.8 \%$ of the dependent variable of MSMEs credit lending distribution can be affected by independent variables of this research.

\section{RESULT}

Based on the results of simultaneous test (F test), it is shown that simultaneously Loan Interest Rate, NonPerforming Loan (NPL), Third Parties Fund (DPK) and Inflation Rate has simultaneous effect on Micro, Small and Medium Enterprises (MSME) Credit Lending
Distribution. This indicates that Loan Interest Rate, NonPerforming Loan, Third Parties Fund, and Inflation Rate are factors that may affect MSMEs credit lending distribution in commercial banks of Indonesia. The results of this study are in line with research conducted [7].

Based on the result of Hypothesis 2 testing, it shows that loan interest rate has positive insignificant effect on MSMEs credit lending distribution in commercial banks of Indonesia. This is in contrast to the theory that lending distribution rates has negative effect on credit lending distribution. High interest should be no problem for the MSMEs, with the condition that consumer purchasing power remains high. The problem is that if larger companies can easily mitigate interest rate risk to the selling price, then it is contrasted to the condition of MSMEs, that could not mitigate the risk. The results of this study support the research conducted by Risnawati (2013).

Based on the result of Hypothesis 3 testing, it showed that non-performing loans (NPL) has negative insignificant effect on MSMEs credit lending distribution in commercial banks of Indonesia. Non-performing loans will lead to decline in bank revenue, and subsequently may lead to decline in profit (Kuncoro and Suhardjono, 2011). In this study[8], the logic behind the insignificant effect of NPL in affecting the MSME credit lending distribution is because of the volume of MSME credit lending is more on the debtor of consumption credit than on the working capital credit and investment. This is one of the reasons that encourages banks to prefer on giving credit to consumer credit lending because it is generally supported by fixed income of the debtor as the source of payment so that is has a higher level of payment certainty compared to other types of credit (Indonesian Economic Report, 2013). This research supporting the research conducted [9][10]

Based on the result of Hypothesis 4 testing, it is showed that Third Party Fund (DPK) has a positive and significant effect on MSMEs credit lending distribution in commercial banks of Indonesia. The results of this study indicates that the increase or decrease in Third Party Fund during the study period affects the credit lending distribution and subsequently affects the growth of bank credit. Third Party Fund has the largest contribution from several sources of funds so that the number of Third Party Fund collected by a bank will affect its ability to distribute credit lending [2]. This study is consistent with previous studies conducted by [11]

Based on the results of Hypothesis 5 testing. It is showed that inflation has a positive insignificant effect on MSMEs credit lending distribution in commercial banks of Indonesia. This is in contrast to the theory which explained that the impact of increasing in inflation will reduce the banks in credit lending distribution [6]. This is because inflation occurring in Indonesia in 20132015 is classified as soft inflation or mild inflation, which is below $10 \%$ per year so that the problems that 
occur can still be controlled by the government. This study supports the research conducted [12].

\section{CONCLUSIONS}

Loan Interest Rate, Non-Performing Loan (NPL), Third Parties Fund (DPK) and Inflation Rate simultaneously affect Micro, Small and Medium Enterprises (MSME) Credit Lending Distribution of commercial banks in Indonesia.Loan Interest Rate has positive insignificant effect on MSME Credit Lending Distribution in Indonesia.Non-performing loan (NPL) has negative insignificant effect on MSME Credit Lending Distribution in Indonesia.Third Party Funds (DPK) has positive significant effect on MSME Credit Lending Distribution in Indonesia.Inflation rate has positive insignificant effect on MSME Credit Lending Distribution in Indonesia.

\section{REFERENCES}

[1] Andini, Rita and Abrar Oemar. Pengaruh Tingkat Suku Bunga Pinjaman, Non-Performing Loan, Dana Pihak Ketiga, Inflasi Dan Produk Domestik Regional Bruto Terhadap Permintaan Kredit Bank Umum Di Jawa Tengah Periode 20092013. Journal of Accounting. 2014.

[2] Kasmir. Bank dan Lembaga Keuangan lainnya Edisi 1 Cetakan 13. Jakarta. Rajawali Pers. 2013.

[3] Citra, Cahya Masturia. Pengaruh NPF, DPK, dan Inflasi tehadap peyaluran Pembiayaan Usaha Kecil Menengah (UKM) di BPRS di Indonesia. Jurnal Ilmu Ekonomi. 2013.

[4] Sukirno, Sadono. Teori Pengantar Mikro Ekonomi. Jakarta: PT Raja Grafindo Persada. 2011.

[5] Triandaru, S and Budi santoso, T. "Bank dan Lembaga Kauangan Lain," Edisi:2. Salemba Empat: Jakarta. 2009.
[6] Firdaus, Rachmat and M. Ariyanti. Pengantar Teori Moneter serta Aplikasinya pada Sistem Ekonomi Konvensional \& Syariah. Bandung. Alfabeta. 2011.

[7] Kaunang, Glently. Tingkat Suku Bunga Pinjaman dan Kredit Macet Pengaruhnya Terhadap Permintaan Kredit UMKM di Indonesia. Jurnal EMBA. Vol 1 No. 3, September 2013. Hal 920. 2013.

[8] Kuncoro, $\mathrm{M}$ and Suhardjono. Manajemen Perbankan: Teori dan Aplikasi, 1st ed. Yogyakarta: BPFE. 2011.

[9] Cahyadi, Yoyo and Arum Pratiwi Puspitasari. Analisis Pengaruh Beberapa Faktor Keuangan Bank Terhadap Jumlah Pemberian Kredit Di Perbankan Indonesia. Journal of Business Strategy and Execution, 7(2). 2012.

[10] Yuda, I Made Pratista and Wahyu Meiranto. Pengaruh Faktor Internal Bank Terhadap Jumlah Kredit Yang Disalurkan (Studi Empiris Pada Bank Yang Terdaftar Di Bursa Efek Indonesia). Jurnal Akuntansi \& Auditing. Vol.7(1). 2011.

[11] Purba, Novyanti Nora, Yusman Syaukat, and tb. Nur Ahmad Maulana. Faktor-Faktor Yang Mempengaruhi tingkat Penyaluran kredit Pada BPR konvensional di Indonesia. Sekolah Bisnis, Institut Pertanian Bogor. Jurnal Aplikasi Bisnis dan Manajemen, Vol. 2(2). 2015.

[12] Sari, Ni Made Junita and Nyoman Abundanti. Pengaruh DPK, ROA, Inflasi Dan Suku Bunga SBI Terhadap Penyaluran Kredit Pada Bank Umum. E-Jurnal Manajemen Unud, Vol. 5, No. 11, 2016: 7156-7184 ISSN: 2302-8912. 2016. 